\title{
DEVELOPMENT OF EUROPEAN SOCIO-ECONOMIC SYSTEMS AND FUTURE CHALLENGES
}

\author{
Martin Kuncl, VŠE
}

\section{Wojciech Bieńkowski, Josef C. Brada and Mariusz-Jan Radło (Eds.) Growth versus Security. Old and New EU Members' Quest for a New Economic and Social Model}

New York, N.Y.: Palgrave Macmillan, 2008, pp. 282. ISBN: 978-0-230-20053-1.

The book Growth versus Security contributes to the long-lasting debate among economists and politicians about the role of government in providing social security and about the costs and benefits of providing social protection. Focusing on the development of socioeconomic systems in Europe, the authors compare their relative efficiency and point to the challenges all countries will have to face in the future. Special attention is devoted to an analysis of the Scandinavian model, which is sometimes referred to as a role model for other countries, and to the transition process in the post-communist countries of Central Europe. The contributions of different economists and politicians from the respective countries are related by their underlying message which is well summarized by the title of the book "Growth versus Security". Most of them suggest that provision of high social security has large and often hidden costs, usually in the form of reduced future growth. They argue that Europe needs more flexible markets and should limit its welfare systems in order to secure its future in the globalized world.
The contributions by fourteen different authors are grouped into three main parts. The first part contains articles which deal with the situation in individual countries, while the second adopts a comparative perspective of the issue. Finally, the last part deals with selected factors that significantly influence the choice of the scope of security provision and the intensity of the orientation toward promotion of future prosperity. The book is written to be accessible to everyone interested in the topic of European socio-economic systems. A few articles use as support simple adaptations of the basic neoclassical growth model but their understanding is not essential for grasping the main ideas of the authors. The book does not have the ambition to present a rigorous technical analysis that would precisely identify the effects of individual microeconomic policies. The approach is usually more general and macroeconomic, though contributions about individual countries are considerably detailed. Most arguments are supported by a descriptive statistical analysis of aggregated data. The 
richness of the contributions makes this book a valuable addition to the old debate about the choice of socio-economic models in Europe.

The first part of the book presents the evolution of socio-economic systems over the last two decades in Sweden and Denmark as representatives of the Scandinavian model and in selected post-communist countries of Central Europe: the Czech Republic, Slovakia and Poland.

The first chapter characterizes the Swedish social system, points to its main problems and describes its reform over the last two decades. It is probably the most interesting chapter of the whole book. Its author, Birgitta Swedenborg, presents a very concise review of results of a large study about the Swedish socio-economic system, jointly carried out by Swedish and American economists. The study was initiated after the economic crisis at the beginning of the 1990s and suggests that one of the causes of the crisis was the build-up of the expensive welfare state in the 1970s and 1980s. From this perspective most recommendations were targeted toward alleviating the negative effects of this system on incentives of the population to work, invest into education, etc. The Swedish socio-economic system is interesting since despite the fact that the lavish social system was mostly preserved even after the reforms of the 1990s, Sweden overcame the crisis and achieved relatively good growth rates at least in comparison to the rest of the old EU member countries. What remains often puzzling for economists is the fact that despite highly market-distorting social interventions and an extremely large public sector, Sweden maintains one of the highest living standards in the world. Also despite a strong policy towards income equalization, unemployment remains relatively low and labour participation high. The chapter tries to address those puzzles. It identifies the incentives in the system that lead to high labour force participation, i.e., the conditioning of welfare benefits on work, but points to significant problems caused by the distorted incentives, such as more sickness leave and early retirement. This chapter is relatively balanced. It recognizes the benefits of increased security, such as the fact that the fruits of growth are shared by all income groups, low criminality, etc.; but at the same time it claims that the costs of those policies are often too excessive.

Brigitta Swedenborg also discusses the costs and benefits of non-market jobs in the public sector. But the most interesting is probably the part of the chapter about the viability of the Swedish system in the future. She correctly draws attention to the fact that industry specialization on skill intensive production will insulate the Swedish system only for a limited time since the product mix of developed and developing countries is being increasingly correlated. Therefore, if Swedes want to sustain at least some income equality in the future, they will have to give up some of it now.

The second chapter focuses on another model that is often considered to be a successful example of a combination of social security provision and a relatively efficient economic system - the so-called flexicurity system in Denmark. The Danish model combines high mobility between jobs with a high level of social security protection for the unemployed.

The author of this chapter, Per Kongshoj Madsen, praises the Danish model but at the same time points out to important difficulties linked to the attempts of introducing this system in other countries. The complexity of the system which is a result of a long political, social and historical evolution makes the system difficult to transfer to other countries. The author argues that a successful establishment of flexicurity requires, among other conditions, both employees and employers to give up existing benefits and lots of mutual trust. This is often missing in many countries.

The remaining of the first part of the book consists of contributions by politicians- 
economists who served as economic ministers in the countries of Central Europe when they were undergoing deep and well needed reforms that either helped to transform the countries from centrally planned economies to market economies or later helped to strengthen the market mechanisms that made the system more efficient. The chapter by Ivan Mikloš, former Slovak Minister of Economy, later the Minister of Finance and also the incumbent Minister of Finance, describes the relatively radical reforms in Slovakia during Dzurinda's governments between 1998 and 2006, which succeeded the government of Vladimír Mečiar that left Slovakia politically isolated and with a stagnating economy. The broad reforms comprised dramatic simplification of taxation including the implementation of a flat tax, pension reform and labour market reform. Mainly thanks to the successful implementation of such reforms, Slovakia became the economic tiger of Central Europe. Mikloš describes, in detail, all major reform steps and their implementation. Another chapter by Karel Dyba, former Czech Minister of Economy, deals with the transition of the Czech economy directly after the fall of the communist regime and reviews the subsequent development of the Czech socio-economic system up to 2007. The most interesting is probably the description of the concept of transition that was adopted by first democratic governments of Czechoslovakia and later the newly born Czech Republic. The realized approach relied on more radical reforms than the piecemeal alternative that was also considered and thus started the relatively successful transformation to a market economy. The chapter by Dyba describes individual reforms of the transformation process, such as the liberalization of prices and foreign trade, privatization, limitation of the role of the government in the economy as well as the importance of the role of a balanced budget and monetary restrictions. Those chapters provide interesting insights into the process of introducing reforms in transition countries and document the importance and positive effects of the reformatory policies. However, it must be noted that some potentially problematic aspects of the transformation process are not treated in much detail. For instance, rapid liberalization of the financial account of the balance of payments without an efficient domestic banking system is from today's perspective somewhat problematic.

The first part of the book concludes with a chapter by Wojciech Bieńkowski that underlines the title of the book by arguing in favour of adopting an Anglo-Saxon socioeconomic model rather than the European continental model or Scandinavian model by Poland. Even though Bieńkowski's article ascribes the recommendation to Poland, the underlying message of most of the chapters is that elements of the Anglo-Saxon model should be adopted by all post-communist countries of Central Europe to achieve sustainable longterm economic prosperity. Bieńkowski's supports his claims by highlighting the Poles' better attitude to business when compared to other nations of Western Europe, which according to him make the Anglo-Saxon model more suitable for Poland. The rest of his arguments are backed by the usual descriptive analysis of statistics of economic growth, productivity, etc.

While the first part of the book consisted of separate analyses of socio-economic systems of particular countries, the second part contains essays on cross-country comparisons. Karl Aiginger defines the European socioeconomic model and its variants such as the Continental, Anglo-Saxon, Mediterranean or Scandinavian model along the lines of the intensity of public responsibility, regulation and redistribution. Unlike other essays in the book, he praises the Scandinavian model pointing mostly to its relative performance with respect to the Continental model. Scandinavian nations with developed welfare state institutions unlike the countries of the Continental system were aware that they need to adopt reforms that would enable them 
to stay competitive while at the same time keeping an extensive welfare system. Karl Aiginger suggest that adopting the qualities of Scandinavian countries, such as the flexicurity, fiscal prudence and governments with consistent long-term strategies and investing into the future could be a sufficient answer to problems the countries using the Continental system are facing. However, he completely omits the fact that even the longterm sustainability of the Scandinavian model may be questionable for reasons enumerated already in the first chapter of this book, not to mention the problems with transposition of institutions.

Steve Hanke in his contribution stresses the importance of institutions for economic growth, notably the need for credible commitment of politicians to the principles of economic freedom that according to him proved very effective in promoting economic growth in countries like Singapore and Estonia.

The last part of the book deals with selected factors that undermine the choice of the amount of social protection and scope of progrowth policies. The contribution by Filip Keereman and Siegfriend Steinlein, both high officials of the European Commission, suggest that the accession process to the EU by countries of Central Europe benefited the acceding countries greatly. They argue that the willingness to join the EU provided an important impetus for the necessary reforms which contributed to the relatively successful beginning of the catch-up process those countries are undertaking. Moreover, the authors suggest that the necessary continuation of the catching-up process can be further catalyzed by EU policies such as the revised Lisbon Strategy, accession to the Eurozone and the Stability and Growth Pact rather than being inspired by the US socio- economic system. The latter view is rather controversial due to the failure of the revised Lisbon Strategy and the inefficiency and unenforceability of the Stability and Growth Pact especially among big countries. The euro also may not be as attractive to Central European countries as suggested by the authors of the article as its net benefits may be limited, which became even more apparent during the recent crisis; though, it is only fair to recall that the book was published in 2008 before the burst of the crisis. I will conclude by mentioning a contribution by Stanisłav Gomułka which deals with the generational difference in preferences about the level of security on one hand and long-term economic growth on the other. He suggests that countries of Central and Eastern Europe with ageing populations may tend to prefer a higher level of security compared to countries with a prevalence of young populations, mostly developing countries like China or India. He also points to serious risks that might be faced by the ageing countries with the domination of people with myopic preferences toward high security and social transfers.

To conclude, the book represents a rich portfolio of contributions from theoreticians as well as practitioners of economic policy. Especially the articles in the first part of the book, which are concerned with individual countries, present a detailed and knowledgeable contribution. A few of the other articles, on the other hand, seem to repeat well known arguments often used by liberal economists and bring relatively few new insights. Altogether the book presents an integral perspective on the old issue of choice of socio-economic models in Europe, and despite it was published in 2008 , it can be recommended to anyone interested in the topic since both the discussion as well as most of the contributions is still current. 